\title{
Neurological Manifestations and Complications of Coronavirus Disease 2019 (COVID-19): A Systematic Review and Meta-Analysis
}

Ahmed Yassin ( $\square$ amyassin@just.edu.jo)

Division of Neurology, Department of Neurosciences, Faculty of Medicine, Jordan University of Science and Technology, Irbid, Jordan https://orcid.org/0000-0002-3175-0408

\section{Mohammed Nawaiseh}

Jordanian Royal Medical Services https://orcid.org/0000-0002-6252-5713

\section{Ala' Shaban}

Jordanian Royal Medical Services https://orcid.org/0000-0003-3053-2158

\section{Khalid Alsherbini}

Department of Neurology, University of Tennessee Health Science Center, Methodist University Hospital, Memphis, TN, USA

\section{Khalid El-Salem}

Division of Neurology, Department of Neurosciences, Faculty of Medicine, Jordan University of Science and Technology, Irbid, Jordan

\section{Ola Soudah}

Department of Basic Medical Sciences, Faculty of Medicine, Yarmouk University, Irbid, Jordan

\section{Mohammad Abu-Rub}

Department of Neurology, The George Washington University, Washington, DC, USA

\section{Systematic Review}

Keywords: COVID-19, coronavirus, neurology, CNS, clinical features, meta-analysis, systematic review

Posted Date: July 7th, 2020

DOI: https://doi.org/10.21203/rs.3.rs-39952/v1

License: (c) (i) This work is licensed under a Creative Commons Attribution 4.0 International License. Read Full License

Version of Record: A version of this preprint was published at BMC Neurology on March 30th, 2021. See the published version at https://doi.org/10.1186/s12883-021-02161-4. 


\section{Abstract}

Background: The spectrum of neurological involvement in COVID-19 is not thoroughly understood. To the best of our knowledge, no systematic review with meta-analysis and a sub-group comparison between severe and non-severe cases has been published. The aim of this study is to assess the frequency of neurological manifestations and complications, identify the neurodiagnostic findings, and compare these aspects between severe and non-severe COVID-19 cases.

Methods: A systematic search of PubMed, Scopus, EBSCO, Web of Science, and Google Scholar databases was conducted for studies published between the 1st of January 2020 and 22nd of April 2020. In addition, we scanned the bibliography of included studies to identify other potentially eligible studies. The criteria for eligibility included studies published in English language (or translated to English), those involving patients with COVID-19 of all age groups, and reporting neurological findings. Data were extracted from eligible studies. Meta-analyses were conducted using comprehensive metaanalysis software. Random-effects model was used to calculate the pooled percentages and means with their $95 \%$ confidence intervals (Cls). Sensitivity analysis was performed to assess the effect of individual studies on the summary estimate. A subgroup analysis was conducted according to severity. The main outcomes of the study were to identify the frequency and nature of neurological manifestations and complications, and the neuro-diagnostic findings in COVID-19 patients.

Results: 44 articles were included with a pooled sample size of 13480 patients. The mean age was 50.3 years and $53 \%$ were males. The most common neurological manifestations were: Myalgia $(22.2 \%, 95 \%$ $\mathrm{Cl}, 17.2 \%$ to $28.1 \%)$, taste impairment $(19.6 \%, 95 \% \mathrm{Cl}, 3.8 \%$ to $60.1 \%)$, smell impairment $(18.3 \%, 95 \% \mathrm{Cl}$, $15.4 \%$ to $76.2 \%)$, headache $(12.1 \%, 95 \% \mathrm{Cl}, 9.1 \%$ to $15.8 \%)$, dizziness $(11.3 \%, 95 \% \mathrm{Cl}, 8.5 \%$ to $15.0 \%)$, and encephalopathy $(9.4 \%, 95 \% \mathrm{Cl}, 2.8 \%$ to $26.6 \%)$. Nearly $2.5 \%(95 \% \mathrm{Cl}, 1 \%$ to $6.1 \%)$ of patients had acute cerebrovascular diseases (CVD). Myalgia, elevated CK and LDH, and acute CVD were significantly more common in severe cases. Moreover, 20 case reports were assessed qualitatively, and their data presented separately.

Conclusions: Neurological involvement is common in COVID-19 patients. Early recognition and vigilance of such involvement might impact their overall outcomes.

\section{Background}

Severe acute respiratory syndrome coronavirus 2 (SARS-CoV-2) has spread rapidly over the past six months causing the Coronavirus Disease 2019 (COVID-19) pandemic. According to Johns Hopkins Coronavirus Resource Center, as of May 29, 2020, 188 nations and more than 5.8 million people across the globe have been affected (1).

Although SARS-CoV-2 primarily affects the respiratory system causing pneumonia, multiorgan dysfunction and failure are likely to occur in severe cases (2). There is mounting evidence that 
coronaviruses can invade the nervous tissue $(3,4)$ resulting in various neurological manifestations $(\mathrm{NM})$ and neurological complications (NC) (5).

The literature about the NM of COVID-19 has been evolving with exponential increase in the number of publications. Multiple studies and case reports described the NM, which vary from being non-specific ones like headache, dizziness, and myalgias to more significant one like ataxia, seizures, anosmia, and ageusia (6-9). Other studies reported NC of COVID-19 like acute ischemic stroke, cerebral venous sinus thrombosis, cerebral hemorrhage, and rhabdomyolysis $(6,10)$. Abnormal findings in neurodiagnostic studies (ND) including neuroimaging (CT and MRI), cerebrospinal fluid (CSF) analysis, and neurophysiological studies (Electroencephalogram (EEG), Nerve Conduction Study (NCS), and Electromyography (EMG)) have also been described $(6,11,12)$.

We conducted a systematic review and meta-analysis of studies addressing the neurological aspects of COVID-19 including NM, NC, and ND findings. In addition, we compared these aspects between severe and non-severe cases. Since the literature is still evolving and not many well designed studies have been published, we also performed a qualitative assessment of the case reports describing some unique NC of COVID-19.

\section{Methods}

We developed a review protocol (registration number: PROSPERO CRD42020181298) prior to commencing the study. The Preferred Reporting Items for Systematic Reviews and Meta-Analyses (PRISMA) were used to ensure the reporting quality of this review (13).

\section{Literature Search Strategy}

A broad search strategy was conducted through the following databases: PubMed, Scopus, EBSCO, Web of Science, and Google Scholar using terms related to COVID-19 and terms related to neurology; more details about the terms used in the search process are available in the appendix (Additional file 1). Primary search process and secondary search process before the final analysis included studies published between January $1^{\text {st }} 2020$ and April $22^{\text {nd }} 2020$. Moreover, additional studies referenced in selected papers were identified and included.

Inclusion and Exclusion Criteria

Inclusion criteria:

- Randomized controlled trials, non-randomized controlled trials, case-control studies, cohort studies, cross sectional studies, case series, and case reports.

- Studies involving patients diagnosed with COVID-19, regardless of age.

- Studies including clinical features of COVID-19 including NM, NC, or ND studies.

- Articles published in English or are otherwise translated to English. 
Exclusion criteria:

- Articles not addressing the neurological aspects of the infection.

- Articles on cases with known neurological conditions before COVID-19 with no major neurological change during the infection (new symptoms or worsening of previous condition).

- Studies addressing any of the other five human coronaviruses.

- Studies published before 2020.

\section{Study Selection}

Four reviewers screened the titles and abstracts of retrieved records for eligibility using Rayyan software (14). Individual studies were critically appraised by applying a standardized appraisal form appropriate for the study type. Inter-rater disagreements were resolved following a discussion between the reviewers.

\section{Data Extraction}

Two reviewers extracted the following information: date of publication, country, study design, age, gender, previous comorbidities, general and neurological clinical features, laboratory findings, imaging findings, neurophysiological study findings, severity and outcome of the disease. We tried to obtain unpublished missing data by contacting authors.

Risk of Bias Assessment

Two reviewers assessed the risk of bias using the NIH Study Quality Assessment Tools for case series, cross sectional and cohort studies $(15,16)$. Conflicts were resolved by consulting a third reviewer.

Data Synthesis and Analysis

We used a random effects model to calculate the pooled percentages for categorical variables and pooled means for continuous variables with their $95 \%$ confidence intervals (Cls) as the effect sizes. For data with median and inter-quartile range (IQR) or median and range, mean and standard deviation (SD) were calculated according to the equations by Luo et.al, Wan et.al, and Hozo et.al (17-19). $\mathrm{I}^{2}$ statistic, $\mathrm{T}^{2}$ (tau-squared) test, and Cochrane $\mathrm{Q}$ were used to assess heterogeneity among studies. Data analysis was done using comprehensive meta-analysis software.

We assessed the existence of publication bias by the Egger's test (20). The existence of publication bias was determined by the degree of the funnel plot symmetry and we considered $P<.05$ as an evidence of the existence of publication bias. 
A subgroup analysis was done to compare clinical and diagnostic neurological features in patients with severe disease compared to patients with non-severe disease; this categorization was determined if the study classified them into these groups Moreover, we performed a sensitivity analysis, in which the pooled estimates for each variable was recalculated, omitting one study at a time, to ensure that none of the included studies affected the results and to examine whether the overall effect size is statistically robust.

\section{Outcome Measures}

The main outcomes of this study were the frequency of NM, NC and ND findings. The main NM included but were not limited to: Headache, myalgia, weakness, dizziness, taste impairment (ageusia), smell impairment (anosmia), altered level of consciousness, behavioral changes, facial weakness, ataxia, abnormal movements (like tremor), hemiparesis, hemiplegia, vision impairment, cranial nerve dysfunction, numbness, paresthesia, and neuropathic pain. The NC included: Ischemic and hemorrhagic strokes, venous sinus thrombosis, meningitis, encephalitis, seizures, and rhabdomyolysis. The ND findings included: Laboratory findings (serum creatine kinase (CK), serum lactate dehydrogenase (LDH), neutrophil count, lymphocyte count, and monocyte count), CSF analysis, neuroimaging (MRI and CT), EEG, NCS, or EMG. Moreover, we examined the treatment associated neurological side effects or complications.

\section{Ratings of the Quality of the Evidence}

According to the modified rating scale of Oxford Centre for Evidence-based Medicine for ratings of individual studies(21), the evidence for most of the studies in our meta-analysis was rated as level four (case series without intervention, and cross sectional) and only two were rated as level three (retrospective cohort studies). Moreover, we included case reports in our qualitative assessment (evidence level four; case reports).

\section{Results}

\section{Study Selection Results}

The primary search yielded 6709 articles, with 41 articles remaining after removal of duplicates and screening titles, abstracts, and full texts. As a result of the rapid growth of the COVID-19 literature, a second search was conducted yielding another 23 articles. Forty-four articles were included in the final meta-analysis and 20 case reports were included in the qualitative descriptive review (Figure 1). Seventeen articles were available on the search databases but they were not yet published in their final form.

\section{Demographics and Characteristics}

Forty-four studies were included in the meta-analysis, 14 of which were available as pre-prints at the time of the search (Table 1). A total of 13480 patients were included in our analysis with a mean age of 50.3 
( $95 \% \mathrm{Cl}, 47.7$ to 52.9$)$ years, and $53 \%(95 \% \mathrm{Cl}, 50.2 \%$ to $55.7 \%)$ being males. Thirty-six (81.8\%) studies were from China, two (4.5\%) were from Italy, and the rest being one from each of Australia, France, Japan, Netherlands, Belgium and the UK. The study sample size ranged from 13 to 6606 patients per study.

The remaining 20 studies were included for the qualitative assessment of case reports (Table 2), three of them were available as pre-prints at the time of the search. These case reports included 57 patients with a mean age of $59.5( \pm 20.2)$ years and $38(67 \%)$ being males.

\section{Risk of Bias Assessment Results}

Of the 44 studies included in the meta-analysis, 39 were considered as case series and they were assessed for risk of bias using the NIH Quality Assessment Tool for Case Series Studies (16). The study quality was rated as good, fair, or poor if the number of "Yes" responses were $\geq 6,3$ to 5 , or $\leq 2$, respectively. Of the 39 -case series, 33 received a "fair" rating and 6 studies received a "good" rating.

Two studies were considered cohort studies and three were considered cross-sectional studies. They were assessed using the NIH Quality Assessment Tool for Observational Cohort and Cross-Sectional Studies (15). The study quality was rated as good, fair, or poor if the number of "Yes" responses were $\geq 9,4$ to 8 , or $\leq 3$, respectively. All of the five included cohort and cross-sectional studies were given a "fair" rating.

Moreover, some questions of the previous quality assessment tools were not applicable to all studies. A more detailed illustration of the risk of bias assessment for each study is attached as a table in the supplementary appendix (Additional files 2 and 3 ).

\section{Clinical features and laboratory findings}

The frequency of NM in COVID-19 patients was as follows: Myalgia (22.2\%, 95\% Cl, $17.2 \%$ to $28.1 \%)$, taste impairment $(19.6 \%, 95 \% \mathrm{Cl}, 3.8 \%$ to $60.1 \%)$, smell impairment $(18.3 \%, 95 \% \mathrm{Cl}, 15.4 \%$ to $76.2 \%)$, headache $(12.1 \%, 95 \% \mathrm{Cl}, 9.1 \%$ to $15.8 \%)$, dizziness $(11.3 \%, 95 \% \mathrm{Cl}, 8.5 \%$ to $15.0 \%)$, encephalopathy or cognitive dysfunction $(9.4 \%, 95 \% \mathrm{Cl}, 2.8 \%$ to $26.6 \%)$, and ataxia or abnormal gait $(2.1 \%, 95 \% \mathrm{Cl}, 0.2 \%$ to $23.7 \%$ ). Nearly, $2.5 \%$ ( $95 \% \mathrm{Cl}, 1 \%$ to $6.1 \%$ ) of COVID-19 patients had acute cerebrovascular diseases (CVD); which included ischemic stroke (IS), intracerebral hemorrhage (ICH), and cerebral venous sinus thrombosis (CVT) (Table 3, additional file 4).

About a third of COVID-19 patients were severely affected (31.1\%, $95 \% \mathrm{Cl}, 21.9 \%$ to $42.2 \%)$ and $20.6 \%$ $(95 \% \mathrm{Cl}, 14.1 \%$ to $29.0 \%)$ were admitted to intensive care units. About $37.4 \%$ (95\% $\mathrm{Cl}, 33.1 \%$ to $41.9 \%)$ had a pre-existing comorbidity, and $5.7 \%(95 \% \mathrm{Cl}, 3.3 \%$ to $9.7 \%)$ had a preexisting neurological disease. Detailed characteristics of the pre-existing comorbidities are presented in (Table $\mathbf{3}$, additional file 5).

Regarding laboratory abnormalities (Table 1, additional file 6), the mean values were as follows: CK: 85.57 U/L (Normal range; 40-200 U/L), LDH: $263.49 \mathrm{U} / \mathrm{L}$ (Normal range; 120-250 U/L). The mean lymphocyte, neutro0phil, and monocyte count were $1.08,3.44$, and $0.39\left({ }^{\star} 10^{\wedge} 9 / \mathrm{L}\right)$, respectively. 
No published data regarding COVID-19 treatment related neurological side effects and complications were found.

\section{Publication Bias}

According to Egger et.al (20), publication bias assessment is only reliable for 10 or more pooled studies. Therefore, we presented the results of publication bias for variables that were discussed in 10 or more studies (Additional file 7). Publication bias was observed in the following variables: fever $(p<.001)$, headache $(p<.001)$, serum LDH $(p=.0015)$, Diabetes Mellitus (DM) $(p=.0089)$, pre-existing neurological diseases $(p=.0089)$, malignancy $(p=.031)$, and chronic kidney disease (CKD) $(p=.044)$.

Sensitivity analysis

A sensitivity analysis, in which the meta-analysis was serially repeated after the exclusion of each study, demonstrated that no individual study affected the overall prevalence for each variable except for the following: Taste impairment prevalence was reduced from $19.6 \%$ to $10.9 \%$ when the study by Spinato et.al was excluded(60); smell impairment prevalence was reduced from $18.3 \%$ to $7.5 \%$ when the study by Lechien et.al was excluded(53), and increased to $35.2 \%$ when the study by Mao et.al was removed (6). After excluding the study conducted by Guan et.al, the reported frequency of NC increased from $3 \%$ to $5.8 \%$ (2). More details can be found in additional file 8.

\section{Subgroup analysis}

When comparing severe to non-severe COVID-19 patients, the severe group included older patients [mean age 60 vs 44.7 years-old, $p<.001]$ and more males [60.3\% vs $48.6 \%, p=.001]$ than the non-severe group. Myalgia [34.9\% vs 4.1\%, $p=.045$ ], acute CVD [34.9\% vs 4.1\%, $p=.045$ ], higher CK value [324.9 vs 121.2 $\mathrm{U} / \mathrm{L}, p=.01$ ] , and higher $\mathrm{LDH}$ value (247.6 vs $83.0 \mathrm{U} / \mathrm{L}, p=.012)$ were more likely in the severe group. While encephalopathy and cognitive dysfunction were more frequent in the severe group $[16.9 \%$ vs $1.9 \%$, $p=.054]$, this was not statistically significant. There was no significant difference for the rest of the variables evaluated (Table 4). Heterogeneity was significant for all the variables and was not resolved by subgroup analysis.

\section{Qualitative assessment}

Twenty case reports (57 patients) were identified and their details are summarized in Table 5. Six (10.5\%) patients were diagnosed with GBS 5-10 days after the onset of respiratory symptoms $(69,72)$. Their neurological symptoms included numbness, weakness, dysphagia, and facial weakness; four patients $(7.0 \%)$ had facial weakness including one (1.8\%) with facial diplegia. All of these patients had abnormal NCS/EMG findings consistent with an axonal variant in three patients and a demyelinating variant in two.

Besides the above-mentioned EMG/NCS abnormalities, ND findings included neuro-imaging, CSF, and EEG findings. Neuro-imaging utilized were head CT, brain MRI and spinal MRI. Six patients had significant neuroimaging findings, including two patients with cerebral hemorrhage $(12,66)$, one patient 
with encephalitis/ventriculitis (11), two GBS patients with enhancement of the caudal nerve roots (72), and one GBS patient with bilateral enhancement of facial nerves (72). Besides, six (10.5\%) patients had CSF changes; mainly increased protein in five $(8,69,72)$, and only one with SARS-CoV-2 RNA detected in CSF using RT-PCR assay (11). Lastly, one patient had EEG changes consisting of bilateral and focal slowing in the left temporal region with left temporal sharp waves (8).

Twelve patients received neurology-related management including IVIG in eight patients, and four who used one or more of the following therapies: ceftriaxone, vancomycin, acyclovir, ganciclovir, steroids, levetiracetam, phenytoin, plasma exchange, or vitamin B12.

Of note, some NM and ND findings were reported by a few studies, out of the 44 studies, and were insufficient to be included in the meta-analysis. These included manifestations like visual impairment (6), nerve pain (6), and diffuse corticospinal tract signs with enhanced tendon reflexes, ankle clonus, and bilateral extensor plantar reflexes (52). CSF findings included positive oligoclonal bands with the same pattern in serum, elevated CSF IgG and CSF protein levels, and low albumin level (52). Head CT findings included ischemic stroke, cerebral hemorrhage, and cerebral venous sinus thrombosis $(6,10)$. Brain MRI findings included leptomeningeal enhancement, bilateral frontotemporal hypoperfusion, and acute and subacute ischemic strokes (52). EEG findings included nonspecific changes and slowing consistent with encephalopathy (52).

\section{Discussion}

A total of 13480 COVID-19 patients were included in the meta-analysis. NM were frequent with around $20 \%$ of patients reporting myalgia, taste impairment, or smell impairment; and around $10 \%$ complaining of headache, dizziness, or encephalopathy. Ataxia or abnormal gait was the least reported NM. Five studies reported NC (CVD, seizures, and rhabdomyolysis). CVDs (IS, ICH, CVT) occurred in $2.5 \%$ of patients. For those who were tested, high levels of CK and LDH as markers of muscle injury were found, especially in the severe subgroup. About one third of patients included in this study had severe disease course and one fifth of them were admitted to the ICU.

There is a mounting evidence that Angiotensin Converting Enzyme 2 (ACE 2) receptors are expressed throughout the central nervous system, primarily on the surface of neurons (79), and SARS-CoV-2 might use these receptors to gain entry into the nervous system $(3,4,80)$. The result of direct neuronal invasion could explain manifestations such as headache, dizziness, ataxia and encephalopathy, while neuronal death and inflammation could explain complications like meningitis/encephalitis $(11,81)$, as well as seizures or even refractory status epilepticus $(82,83)$. Interestingly, direct invasion of the respiratory centers in the brainstem was proposed as a contributing factor to the respiratory failure in COVID-19 patients $(3,84)$.

Viral entry into the CNS is debatable. This could happen via a hematogenous route in which the virus passes through the blood brain barrier (BBB) by transcytosis or infects endothelial or epithelial cells to 
cross the BBB $(4,11)$. Alternatively, the virus could infect and get transported by leukocytes into the CNS, as was shown for SARS-CoV(85).

Moreover, ACE 2 receptor is heavily expressed on the epithelial cells of the mucosa of the oral cavity (86) and a trans-neural transmission of SARS-CoV through the olfactory bulb was seen in a mice model (87). These findings could explain the occurrence of anosmia and ageusia in COVID-19 patients, which at times can be the only presenting features or the very early symptoms of COVID 19(53).

Myalgia and occasionally clinically significant muscle injury in severe disease, as evidenced by elevated $\mathrm{CK}$ and $\mathrm{LDH}$, can be either a direct response of viral invasion of the skeletal muscles, which are also known to express ACE2 receptor(80), or an indirect response to the systemic inflammatory reaction manifested by a cytokine storm, subsequently causing muscle injury $(88,89)$.

Multiple mechanisms could explain the increased risk of ischemic strokes and venous sinus thrombosis; these include hypercoagulability (6), high systemic inflammatory response or "cytokine storm" (90), vascular endothelial injury (59), and cardiac injury resulting in cerebral embolism (91).

According to our analysis, myalgia and evidence of muscle injury "elevated CK and LDH" as well as CVD were more likely to occur with severe disease. This might be related to the degree of the inflammatory response and the reported cytokine release syndrome (92) as well as the prothrombotic state (93) that occur with severe cases of COVID-19 and contribute to the multiorgan failure $(22,94)$.

Congruent with what Mao et al(6) reported in the first retrospective observational case series describing the NM of COVID-19 in 214 hospitalized patients in Wuhan-China, our meta-analysis shows that myalgia or skeletal muscle injury (with elevated LDH and CK) and acute CVDs are predominantly associated with severe COVID-19.

A recent systematic review of 8 studies (95), not including a meta-analysis, suggested that some patients, particularly those with severe illness, have CNS involvement and NM, which is supported by the results of our study. Montalvan et al (96) concluded that symptoms of hyposmia, headaches, weakness, and altered consciousness, and complications like encephalitis, demyelination, neuropathy, and stroke were associated with coronaviruses infections. Those results are congruent with our findings, although we looked at SARS-CoV-2 exclusively, while they evaluated other human coronaviruses in addition. The authors also suggested that trans-synaptic extension through the cribriform plate and olfactory bulb represents the main mechanism of neuro-invasion, and that invasion of the medulla could contribute to the respiratory failure in critically ill COVID-19 patients. Ahmad et al (97) in a narrative literature review reported that neurological features could occur before the classical features of COVID-19 like fever and cough, and accordingly a high index of suspicion is needed for a timely diagnosis and isolation of cases.

In the 20 case reports we evaluated, the most common NM included fatigue, myalgia, and smell and taste impairment, which is quite similar to our meta-analysis results. NC included GBS (6 cases), encephalitis, seizures, ICH, IS, myelitis and rhabdomyolysis. GBS associated with COVID-19 indicates that SARS CoV-2 
can potentially induce an immune response that results in a delayed neurological complication (98). This association between coronaviruses and GBS was reported before $(98,99)$. In these case reports, the neurological outcome was variable, but one fourth of patients were left with residual deficits after 2 weeks of COVID-19 disease onset, indicating potential severity of the neurological injury.

\section{Quality of the Evidence}

We believe that the evidence generated from our meta-analysis is reliable since it is based on fair to good quality studies and well-defined search methods and eligibility criteria. More than 40 studies in varied populations have been included in the final meta-analysis, with emphasis on avoiding overlapping data. In addition, we performed a subgroup analysis to test if there is an association between neurological manifestations of COVID-19 and severity of the disease. We followed the Preferred Reporting Items for Systematic Reviews and Meta-Analyses (PRISMA) checklist to prepare this study (13).

\section{Limitations}

Limitations of our analysis include the heterogeneity among the studies being considerably high both in the overall population and following the subgroup analysis. This is due to the large variation in the sample size among studies, the different study designs and methodologies, and possibly reflecting a true variation between different populations. A random effect model was set a priori since significant heterogeneity was expected. Besides, most of the included studies collected the data retrospectively. Finally, egger test indicated that there is a possible publication bias among the following variables: Fever, headache, serum LDH, DM, pre-existing neurological diseases, malignancy, and CKD. There is a possibility that some unpublished studies were not identified as our meta-analysis was limited to studies published in English-language and since many studies were not yet published at the time of screening. However, we tried to avoid publication bias by including studies translated into English as well as including pre-prints and contacting authors.

\section{Conclusion}

In this meta-analysis on the neurological features of COVID-19, we found that several NM and NC are associated with COVID-19, and certain features, such as CVD, muscle injury, and probably encephalopathy, might be associated with severe disease status. Healthcare professional dealing with COVID-19, neurologists, and the general public should be aware of the neurological involvement of the disease. Patients of possible COVID-19 presenting with the previously mentioned neurological features should trigger clinical suspicion. Further studies are required to assess the prevalence of the neurological aspects of COVID-19 in different populations and to directly compare them between severe and nonsevere subgroups. More pathophysiological analysis and studies are required as well in order to understand the exact mechanism through which the virus affects the nervous system.

\section{List Of Abbreviations}


EEG: Electroencephalography

EMG: Electromyography

CK: Creatine Kinase

CNS: Central Nervous System

COVID-19: Coronavirus Disease 2019

CSF: Cerebrospinal Fluid

CT: Computed Tomography

LDH: Lactate Dehydrogenase

MRI: Magnetic Resonance Imaging

NCS: Nerve Conduction Study

SARS-CoV-2: Severe Acute Respiratory Syndrome Coronavirus 2

PRISMA: Preferred Reporting Items for Systematic Reviews and Meta-Analyses

BBB: Blood Brain Barrier

NM: Neurological Manifestations

NC: Neurological Complications

ND: Neurodiagnostic

\section{Declarations}

Ethics approval and consent to participate

Not applicable.

Consent for publication

Not applicable.

Availability of data and materials

All data synthesized and analyzed are included in this published article.

Competing interests 
The authors declare that they have no competing interests.

\section{Funding}

No funding was obtained.

\section{Acknowledgements}

Not applicable.

\section{Authors' information}

Ahmed Yassin, Mohammed Nawaiseh, and Ala' Shaban contributed equally and are co-first authors.

\section{Affiliation}

Division of Neurology, Department of Neurosciences, Faculty of Medicine, Jordan University of Science and Technology, Irbid, Jordan

Ahmed Yassin and Khalid El-Salem

Intern at Jordanian Royal Medical Services, Amman, Jordan

Mohammed Nawaiseh and Ala' Shaban

Department of Neurology, University of Tennessee Health Science Center, Methodist University Hospital, Memphis, TN, USA

Khalid Alsherbini

Department of Basic Medical Sciences, Faculty of Medicine, Yarmouk University, Irbid, Jordan

Ola Soudah

\section{Department of Neurology, The George Washington University, Washington, DC, USA}

Mohammad Abu-Rub

\section{Contribution}

AY designed the study, searched the literature, screened the records, assessed the risk of bias, and drafted and revised the manuscript. MN designed the study, searched the literature, extracted and synthesized the data, undertook statistical analyses and interpretation, and drafted the manuscript. AA designed the study, searched the literature, assessed the risk of bias, extracted and synthesized the data, and drafted the manuscript. KA screened the records, interpreted the data, and drafted and revised the manuscript. KE screened the records, interpreted the data, and drafted and revised the manuscript. OS undertook 
statistical analyses and interpretation, and revised the manuscript. MA screened the records, assessed the risk of bias, and drafted and revised the manuscript.

\section{Qualifications}

- AY is an Assistant Professor of Neurology and Neurology Residency Program Director at Jordan University of Science and Technology/ King Abdullah University Hospital. He did his Neurology residency and Clinical Neurophysiology and Epilepsy fellowships in the United States. He has the American Boards in Neurology, Clinical Neurophysiology, Epilepsy and Medical Quality.

- MN graduated from the Medical School of The University of Jordan in 2019, ranking in the top $5^{\text {th }} \mathrm{He}$ is currently an intern at Royal Medical Services and is pursuing to do his residency training in Ophthalmology at the United Kingdom next year. At the same time, he is an active researcher with expertise in conducting meta-analysis and collaborates with Faculty members from different Jordanian universities in multiple research projects.

- AS graduated from the Medical School of The University of Jordan in 2019, ranking in the top $5^{\text {th }} \mathrm{He}$ is currently an intern at Royal Medical Services and is pursuing to do his residency training in Neurology at the United States next year. At the same time, he is an active researcher with vast skills in conducting systematic reviews and meta-analysis and collaborates with neurologists from different Jordanian institutions in multiple research projects.

- KA is an Associate Professor of Neurology and Neurosurgery, Director of EEG Department, and Neurocritical Care Fellowship Program Director at the University of Tennessee Health Science Center Methodist University Hospital. He has American Boards in Neurology, Epilepsy, and Neurocritical Care Medicine.

- KE is a Professor of Neurology and Vice President of Jordan University of Science and Technology. He did his Neurology residency and Clinical Neurophysiology and Neuromuscular fellowships in the United States. He has the American Boards in Neurology, Clinical Neurophysiology, Neuromuscular Medicine and Electrodiagnostic Medicine. He is a Fellow of the American Academy of Neurology (FAAN). He ranked among the top publishing and highly cited researchers in the country in 2019 and remains the top cited in the field of adult neurology in Jordan.

- OS is an Assistant Professor of Community Medicine and Public Health at Yarmouk University in Jordan. She earned her PhD in Clinical Sciences/ Health Services research track from Preventive Medicine and Community Health School at University of Texas Medical Branch/Galveston-TX-USA.

- MA is an Assistant Professor of Neurology at The George Washington University. He has American Boards in Neurology, Clinical Neurophysiology and Epilepsy. He is the Director of Continuing Medical Education (CME) in the Department of Neurology and Co-Director of the Transcranial Magnetic Stimulation (TMS Unit. He is also a research associate at the Department of Anatomy and Regenerative Medicine.

\section{Corresponding author}




\section{References}

1. Hopkins J. Corona virus resource center. Im Internet Stand 19042020 Httpscoronavirus Jhu Edudata. 2020;

2. Guan W, Ni Z, Hu Y, Liang W, Ou C, He J, et al. Clinical characteristics of coronavirus disease 2019 in China. N Engl J Med. 2020;382(18):1708-20.

3. Li Y-C, Bai W-Z, Hashikawa T. The neuroinvasive potential of SARS-CoV2 may play a role in the respiratory failure of COVID-19 patients. J Med Virol. 2020;

4. Desforges M, Le Coupanec A, Dubeau P, Bourgouin A, Lajoie L, Dubé M, et al. Human Coronaviruses and Other Respiratory Viruses: Underestimated Opportunistic Pathogens of the Central Nervous System? Viruses. 2020;12(1):14.

5. Pleasure SJ, Green AJ, Josephson SA. The spectrum of neurologic disease in the severe acute respiratory syndrome coronavirus 2 pandemic infection: neurologists move to the frontlines. JAMA Neurol. 2020;

6. Mao L, Wang M, Chen S, He Q, Chang J, Hong C, et al. Neurological manifestations of hospitalized patients with COVID-19 in Wuhan, China: a retrospective case series study. 2020;

7. Xiang P, Xu XM, Gao LL, Wang HZ, Xiong HF, Li RH. First case of 2019 novel coronavirus disease with Encephalitis. ChinaXiv. 2020;202003:00015.

8. Filatov A, Sharma P, Hindi F, Espinosa PS. Neurological complications of coronavirus disease (COVID-19): encephalopathy. Cureus. 2020;12(3).

9. Marchese-Ragona R, Ottaviano G, Nicolai P, Vianello A, Carecchio M. Sudden hyposmia as a prevalent symptom of COVID-19 infection. medRxiv. 2020;

10. Li Y, Wang M, Zhou Y, Chang J, Xian Y, Mao L, et al. Acute cerebrovascular disease following COVID19: a single center, retrospective, observational study. 2020;

11. Moriguchi T, Harii N, Goto J, Harada D, Sugawara H, Takamino J, et al. A first Case of Meningitis/Encephalitis associated with SARS-Coronavirus-2. Int J Infect Dis. 2020;

12. Poyiadji N, Shahin G, Noujaim D, Stone M, Patel S, Griffith B. COVID-19-associated acute hemorrhagic necrotizing encephalopathy: CT and MRI features. Radiology. 2020;201187.

13. Liberati A, Altman DG, Tetzlaff J, Mulrow C, Gøtzsche PC, loannidis JP, et al. The PRISMA statement for reporting systematic reviews and meta-analyses of studies that evaluate health care interventions: explanation and elaboration. J Clin Epidemiol. 2009;62(10):e1-34.

14. Ouzzani M, Hammady H, Fedorowicz Z, Elmagarmid A. Rayyan-a web and mobile app for systematic reviews. Systematic Reviews, 5 (210). 2016.

15. Health NI of. National Heart Lung, and Blood Institute. Quality assessment tool for observational cohort and cross-sectional studies. 2014. 
16. Health NI of. Quality Assessment tool for case series studies. The National Heart, Lung, and Blood Institute; 2017.

17. Luo D, Wan X, Liu J, Tong T. Optimally estimating the sample mean from the sample size, median, mid-range, and/or mid-quartile range. Stat Methods Med Res. 2018;27(6):1785-805.

18. Wan X, Wang W, Liu J, Tong T. Estimating the sample mean and standard deviation from the sample size, median, range and/or interquartile range. BMC Med Res Methodol. 2014;14(1):135.

19. Hozo SP, Djulbegovic B, Hozo I. Estimating the mean and variance from the median, range, and the size of a sample. BMC Med Res Methodol. 2005;5(1):13.

20. Egger M, Smith GD, Schneider M, Minder C. Bias in meta-analysis detected by a simple, graphical test. Bmj. 1997;315(7109):629-34.

21. Group OL of EW. The Oxford levels of evidence 2: Oxford centre for evidence-based medicine. University of Oxford; 2011.

22. Chen G, Wu D, Guo W, Cao Y, Huang D, Wang H, et al. Clinical and immunologic features in severe and moderate forms of Coronavirus Disease. J Clin Invest. 2019;137244.

23. Liu L, Zhang DC, Tang SG. The epidemiological and clinical characteristics of 2019 novel coronalvirus infection in Changsha. Available at SSRN 3537093. China;

24. Wang L, Gao Y-H, Lou L-L, Zhang G-J. The clinical dynamics of 18 cases of COVID-19 outside of Wuhan, China. Eur Respir J. 2020;55(4).

25. Giacomelli A, Pezzati L, Conti F, Bernacchia D, Siano M, Oreni L. Self-reported olfactory and taste disorders in SARS-CoV-2 patients: a cross-sectional study [published online March 26, 2020]. Clin Infect Dis.

26. Xu X, Yu C, Qu J, Zhang L, Jiang S, Huang D, et al. Imaging and clinical features of patients with 2019 novel coronavirus SARS-CoV-2. Eur J Nucl Med Mol Imaging. 2020;1-6.

27. Jin X, Lian J-S, Hu J-H, Gao J, Zheng L, Zhang Y-M, et al. Epidemiological, clinical and virological characteristics of 74 cases of coronavirus-infected disease 2019 (COVID-19) with gastrointestinal symptoms. Gut. 2020;69(6):1002-9.

28. Chen N, Zhou M, Dong X, Qu J, Gong F, Han Y, et al. Epidemiological and clinical characteristics of 99 cases of 2019 novel coronavirus pneumonia in Wuhan, China: a descriptive study. The Lancet. 2020;395(10223):507-13.

29. Li J, Li S, Cai Y, Liu Q, Li X, Zeng Z, et al. Epidemiological and Clinical Characteristics of 17 Hospitalized Patients with 2019 Novel Coronavirus Infections Outside Wuhan, China. medRxiv. 2020;

30. Qian G-Q, Yang N-B, Ding F, Ma AHY, Wang Z-Y, Shen Y-F, et al. Epidemiologic and Clinical Characteristics of 91 Hospitalized Patients with COVID-19 in Zhejiang, China: A retrospective, multicentre case series. QJM Int J Med. 2020;

31. Xu X-W, Wu X-X, Jiang X-G, Xu K-J, Ying L-J, Ma C-L, et al. Clinical findings in a group of patients infected with the 2019 novel coronavirus (SARS-Cov-2) outside of Wuhan, China: retrospective case series. bmj. 2020;368. 
32. Huang C, Wang Y, Li X, Ren L, Zhao J, Hu Y, et al. Clinical features of patients infected with 2019 novel coronavirus in Wuhan, China. The lancet. 2020;395(10223):497-506.

33. Wan S, Xiang Y, Fang W, Zheng Y, Li B, Hu Y, et al. Clinical features and treatment of COVID-19 patients in northeast Chongqing. J Med Virol. 2020;

34. Yang $X, Y u Y, X u J$, Shu H, Liu H, Wu Y, et al. Clinical course and outcomes of critically ill patients with SARS-CoV-2 pneumonia in Wuhan, China: a single-centered, retrospective, observational study. Lancet Respir Med. 2020;

35. Liu K, Fang Y-Y, Deng Y, Liu W, Wang M-F, Ma J-P, et al. Clinical characteristics of novel coronavirus cases in tertiary hospitals in Hubei Province. Chin Med J (Engl). 2020;

36. Wang D, Hu B, Hu C, Zhu F, Liu X, Zhang J, et al. Clinical characteristics of 138 hospitalized patients with 2019 novel coronavirus-infected pneumonia in Wuhan, China. Jama. 2020;323(11):1061-9.

37. Qin X, Qiu S, Yuan Y, Zong Y, Tuo Z, Li J, et al. Clinical characteristics and treatment of patients infected with COVID-19 in Shishou, China. China Febr 18 2020. 2020;

38. Yang W, Cao Q, Qin L, Wang X, Cheng Z, Pan A, et al. Clinical characteristics and imaging manifestations of the 2019 novel coronavirus disease (COVID-19): A multi-center study in Wenzhou city, Zhejiang, China. J Infect. 2020;

39. Qin C, Zhou L, Hu Z, Zhang S, Yang S, Tao Y, et al. Dysregulation of immune response in patients with COVID-19 in Wuhan, China. Clin Infect Dis. 2020;

40. Liu J, Liu Y, Xiang P, Pu L, Xiong H, Li C, et al. Neutrophil-to-lymphocyte ratio predicts severe illness patients with 2019 novel coronavirus in the early stage. MedRxiv. 2020;

41. Easom N, Moss P, Barlow G, Samson A, Taynton T, Adams K, et al. Sixty-eight consecutive patients assessed for COVID-19 infection: Experience from a UK Regional infectious diseases Unit. Influenza Other Respir Viruses. 2020;

42. Deng Y, Liu W, Liu K, Fang Y-Y, Shang J, Wang K, et al. Clinical characteristics of fatal and recovered cases of coronavirus disease 2019 (COVID-19) in Wuhan, China: a retrospective study. Chin Med J (Engl). 2020;

43. Huang $Y$, Tu M, Wang S, Chen S, Zhou W, Chen D, et al. Clinical characteristics of laboratory confirmed positive cases of SARS-CoV-2 infection in Wuhan, China: A retrospective single center analysis. Travel Med Infect Dis. 2020;

44. Mo P, Xing Y, Xiao Y, Deng L, Zhao Q, Wang H, et al. Clinical characteristics of refractory COVID-19 pneumonia in Wuhan, China. Clin Infect Dis. 2020;

45. Zheng F, Tang W, Li H, Huang YX, Xie YL, Zhou ZG. Clinical characteristics of 161 cases of corona virus disease 2019 (COVID-19) in Changsha. Eur Rev Med Pharmacol Sci. 2020;24(6):3404-10.

46. Guo T-M, Tong Y, Chen J, Huang L, Cheng B, Zhoue J. Clinical Features Predicting Mortality Risk in Older Patients with COVID-19. Available SSRN 3569846. 2020;

47. Yan X, Wang C, Peng D, Han X, Fan Y, Fang Z, et al. Clinical Features, Treatment and Outcomes of 218 Patients with COVID-19: A Retrospective, Multicenter Study Based on Clinical Classification. 
Treat Outcomes Of. 2020;218.

48. Chang D, Lin M, Wei L, Xie L, Zhu G, Cruz CSD, et al. Epidemiologic and clinical characteristics of novel coronavirus infections involving 13 patients outside Wuhan, China. Jama. 2020;323(11):1092-3.

49. Wang R, Pan M, Zhang X, Fan X, Han M, Zhao F, et al. Epidemiological and clinical features of 125 Hospitalized Patients with COVID-19 in Fuyang, Anhui, China. Int J Infect Dis. 2020;

50. Zhou Z, Zhou J, Sun J, Cao Z, Wang W, Huang K, et al. Epidemiological and clinical features of 201 COVID-19 patients in Changsha, China. 2020;

51. Zheng Y, Xu H, Yang M, Zeng Y, Chen H, Liu R, et al. Epidemiological characteristics and clinical features of 32 critical and 67 noncritical cases of COVID-19 in Chengdu. J Clin Virol. 2020;104366.

52. Helms J, Kremer S, Merdji H, Clere-Jehl R, Schenck M, Kummerlen C, et al. Neurologic features in severe SARS-CoV-2 infection. N Engl J Med. 2020;

53. Lechien JR, Chiesa-Estomba CM, De Siati DR, Horoi M, Le Bon SD, Rodriguez A, et al. Olfactory and gustatory dysfunctions as a clinical presentation of mild-to-moderate forms of the coronavirus disease (COVID-19): a multicenter European study. Eur Arch Otorhinolaryngol. 2020;1-11.

54. Chen W, Chen C, Huang L, Ye K, Lv L, Qin Z, et al. Clinical Characteristics of 85 Patients Infected by SARS-CoV-2 in Guangxi, China. 2020;

55. Jiang X, Tao J, Wu H, Wang Y, Zhao W, Zhou M, et al. Clinical features and management of severe COVID-19: A retrospective study in Wuxi, Jiangsu Province, China. medRxiv. 2020;

56. Zhang G, Hu C, Luo L, Fang F, Chen Y, Li J, et al. Clinical features and short-term outcomes of 221 patients with COVID-19 in Wuhan, China. J Clin Virol. 2020;104364.

57. Tabata S, Imai K, Kawano S, Ikeda M, Kodama T, Miyoshi K, et al. The clinical characteristics of COVID-19: a retrospective analysis of 104 patients from the outbreak on board the Diamond Princess cruise ship in Japan. medRxiv. 2020;

58. Lei Z, Cao H, Jie Y, Huang Z, Guo X, Chen J, et al. A cross-sectional comparison of epidemiological and clinical features of patients with coronavirus disease (COVID-19) in Wuhan and outside Wuhan, China. Travel Med Infect Dis. 2020;101664.

59. Zhou F, Yu T, Du R, Fan G, Liu Y, Liu Z, et al. Clinical course and risk factors for mortality of adult inpatients with COVID-19 in Wuhan, China: a retrospective cohort study. The lancet. 2020;

60. Spinato G, Fabbris C, Polesel J, Cazzador D, Borsetto D, Hopkins C, et al. Alterations in smell or taste in mildly symptomatic outpatients with SARS-CoV-2 infection. Jama. 2020;

61. Klok FA, Kruip M, Van der Meer NJM, Arbous MS, Gommers D, Kant KM, et al. Confirmation of the high cumulative incidence of thrombotic complications in critically ill ICU patients with COVID-19: An updated analysis. Thromb Res. 2020;

62. COVID-19, Australia: Epidemiology Report 12 (Reporting week to 23:59 AEST 19 April 2020). Commun Dis Intell 2018. 2020 Apr 24;44. 
63. Zhao K, Huang J, Dai D, Feng Y, Liu L, Nie S. Acute myelitis after SARS-CoV-2 infection: a case report. MedRxiv. 2020;

64. Villalba NL, Maouche Y, Ortiz MBA, Sosa ZC, Chahbazian JB, Syrovatkova A, et al. Anosmia and Dysgeusia in the Absence of Other Respiratory Diseases: Should COVID-19 Infection Be Considered? Eur J Case Rep Intern Med. 2020;7(4).

65. Ollarves-Carrero MF, Rodriguez-Morales AG, Bonilla-Aldana DK, Rodriguez-Morales AJ. Anosmia in a healthcare worker with COVID-19 in Madrid, Spain. Travel Med Infect Dis. 2020;

66. Sharifi-Razavi A, Karimi N, Rouhani N. COVID-19 and intracerebral haemorrhage: causative or coincidental? New Microbes New Infect. 2020;35.

67. Novi G, Mikulska M, Briano F, Toscanini F, Tazza F, Uccelli A, et al. COVID-19 in a MS patient treated with ocrelizumab: does immunosuppression have a protective role? Mult Scler Relat Disord. 2020;102120.

68. Karimi N, Sharifi Razavi A, Rouhani N. Frequent convulsive seizures in an adult patient with COVID19: a case report. Iran Red Crescent Med J. 2020;(In Press).

69. Zhao H, Shen D, Zhou H, Liu J, Chen S. Guillain-Barré syndrome associated with SARS-CoV-2 infection: causality or coincidence? Lancet Neurol. 2020;19(5):383-4.

70. Gane SB, Kelly C, Hopkins C. Isolated sudden onset anosmia in COVID-19 infection. A novel syndrome. Rhinology. 2020;58(3):0-0.

71. Hjelmesæth J, Skaare D. Loss of smell or taste as the only symptom of COVID-19. Tidsskr Den Nor Legeforening. 2020;

72. Toscano G, Palmerini F, Ravaglia S, Ruiz L, Invernizzi P, Cuzzoni MG, et al. Guillain-Barré syndrome associated with SARS-CoV-2. N Engl J Med. 2020;

73. Suwanwongse K, Shabarek N. Rhabdomyolysis as a presentation of 2019 novel coronavirus disease. Cureus. 2020;12(4).

74. Wang J, Hajizadeh N, Moore EE, Mclntyre RC, Moore PK, Veress LA, et al. Tissue plasminogen activator (tpa) treatment for COVID-19 associated acute respiratory distress syndrome (ARDS): a case series. J Thromb Haemost. 2020;

75. Wang Z, Chen X, Lu Y, Chen F, Zhang W. Clinical characteristics and therapeutic procedure for four cases with 2019 novel coronavirus pneumonia receiving combined Chinese and Western medicine treatment. Biosci Trends. 2020;

76. Ren L-L, Wang Y-M, Wu Z-Q, Xiang Z-C, Guo L, Xu T, et al. Identification of a novel coronavirus causing severe pneumonia in human: a descriptive study. Chin Med J (Engl). 2020;

77. Rothe C, Schunk M, Sothmann P, Bretzel G, Froeschl G, Wallrauch C, et al. Transmission of 2019nCoV infection from an asymptomatic contact in Germany. N Engl J Med. 2020;382(10):970-1.

78. Wang W, Tang J, Wei F. Updated understanding of the outbreak of 2019 novel coronavirus (2019nCoV) in Wuhan, China. J Med Virol. 2020;92(4):441-7. 
79. Chen R, Yu J, Wang K, Howard D, French L, Chen Z, et al. The spatial and cell-type distribution of SARS-CoV-2 receptor ACE2 in human and mouse brain. bioRxiv. 2020;

80. Hamming I, Timens W, Bulthuis MLC, Lely AT, Navis GJ, van Goor H. Tissue distribution of ACE2 protein, the functional receptor for SARS coronavirus. A first step in understanding SARS pathogenesis. J Pathol J Pathol Soc G B Irel. 2004;203(2):631-7.

81. Ye M, Ren Y, Lv T. Encephalitis as a clinical manifestation of COVID-19. Brain Behav Immun. 2020;

82. Robinson CP, Busl KM. Neurologic manifestations of severe respiratory viral contagions. Crit Care Explor. 2020;2(4).

83. Sohal S, Mossammat M. COVID-19 Presenting with Seizures. IDCases. 2020;e00782.

84. Nath A. Neurologic complications of coronavirus infections. Neurology. 2020 May 12;94(19):809-10.

85. Gu J, Gong E, Zhang B, Zheng J, Gao Z, Zhong Y, et al. Multiple organ infection and the pathogenesis of SARS. J Exp Med. 2005;202(3):415-24.

86. Xu H, Zhong L, Deng J, Peng J, Dan H, Zeng X, et al. High expression of ACE2 receptor of 2019-nCoV on the epithelial cells of oral mucosa. Int J Oral Sci. 2020;12(1):1-5.

87. Netland J, Meyerholz DK, Moore S, Cassell M, Perlman S. Severe acute respiratory syndrome coronavirus infection causes neuronal death in the absence of encephalitis in mice transgenic for human ACE2. J Virol. 2008;82(15):7264-75.

88. Cabello-Verrugio C, Morales MG, Rivera JC, Cabrera D, Simon F. Renin-angiotensin system: an old player with novel functions in skeletal muscle. Med Res Rev. 2015;35(3):437-63.

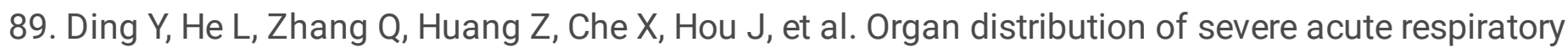
syndrome (SARS) associated coronavirus (SARS-CoV) in SARS patients: implications for pathogenesis and virus transmission pathways. J Pathol J Pathol Soc G B Irel. 2004;203(2):622-30.

90. Mehta P, McAuley DF, Brown M, Sanchez E, Tattersall RS, Manson JJ. COVID-19: consider cytokine storm syndromes and immunosuppression. The Lancet. 2020;395(10229):1033-4.

91. Akhmerov A, Marbán E. COVID-19 and the Heart. Circ Res. 2020;126(10):1443-55.

92. Moore JB, June CH. Cytokine release syndrome in severe COVID-19. Science. 2020;368(6490):473-4.

93. Spiezia L, Boscolo A, Poletto F, Cerruti L, Tiberio I, Campello E, et al. COVID-19-related severe hypercoagulability in patients admitted to intensive care unit for acute respiratory failure. Thromb Haemost. 2020;

94. Ruan Q, Yang K, Wang W, Jiang L, Song J. Clinical predictors of mortality due to COVID-19 based on an analysis of data of 150 patients from Wuhan, China. Intensive Care Med. 2020;1-3.

95. Asadi-Pooya AA, Simani L. Central nervous system manifestations of COVID-19: A systematic review. J Neurol Sci. 2020;116832.

96. Montalvan V, Lee J, Bueso T, De Toledo J, Rivas K. Neurological manifestations of COVID-19 and other coronavirus infections: A systematic review. Clin Neurol Neurosurg. 2020;194:105921.

97. Ahmad I, Rathore FA. Neurological manifestations and complications of COVID-19: A Literature Review. J Clin Neurosci. 2020; 
98. Kim J-E, Heo J-H, Kim H, Song S, Park S-S, Park T-H, et al. Neurological complications during treatment of Middle East respiratory syndrome. J Clin Neurol. 2017;13(3):227-33.

99. Sharma K, Tengsupakul S, Sanchez O, Phaltas R, Maertens P. Guillain-Barré syndrome with unilateral peripheral facial and bulbar palsy in a child: A case report. SAGE Open Med Case Rep. 2019;7:2050313X19838750.

\section{Tables}

Table1: Characteristics of the Included Studies in the Meta-Analysis of the Neurological Features of COVID-19 


\begin{tabular}{|c|c|c|c|c|c|c|c|c|}
\hline \# & Author & $\begin{array}{c}\text { Date } \\
(\mathrm{DD} / \mathrm{MM} / \mathrm{Y})\end{array}$ & Journal & Study type & $\mathbf{N}$ & Country & Reference & $\begin{array}{l}\text { Study } \\
\text { quality }\end{array}$ \\
\hline 1 & $\begin{array}{l}\text { Chen and Wu, } \\
2020\end{array}$ & $27-3-2020$ & The Journal of Clinical Investigation & Case series & 21 & China & $(22)$ & Fair \\
\hline 2 & $\begin{array}{l}\text { Liu and Zhang, } \\
2020\end{array}$ & $\begin{array}{l}\text { Pre-print: } 13- \\
2-2020\end{array}$ & The Lancet Infectious Diseases & Case series & 24 & China & (23) & Fair \\
\hline 3 & $\begin{array}{l}\text { Wang and Gao, } \\
2020\end{array}$ & $\begin{array}{l}\text { Pre-proof: 5- } \\
\text { 3-2020 }\end{array}$ & European Respiratory Journal & Case series & 18 & China & $(24)$ & Fair \\
\hline 4 & $\begin{array}{l}\text { Giacomelli, } \\
2020\end{array}$ & $26-3-2020$ & Clinical Infectious Diseases & $\begin{array}{l}\text { Cross-Sectional } \\
\text { Study }\end{array}$ & 59 & Italy & (25) & Fair \\
\hline 5 & Mao, 2020 & $10-4-2020$ & JAMA Neurology & Case series & 214 & China & (6) & Fair \\
\hline 6 & $\begin{array}{l}\mathrm{Xu} \text { and } \mathrm{Yu} \text {, } \\
2020\end{array}$ & $28-2-2020$ & $\begin{array}{c}\text { European Journal of Nuclear Medicine } \\
\text { and Molecular Imaging }\end{array}$ & Case series & 90 & China & (26) & Fair \\
\hline 7 & Jin, 2020 & $24-3-2020$ & BMJ & Case series & 651 & China & (27) & Fair \\
\hline 8 & $\begin{array}{l}\text { Chen and } \\
\text { Zhou, } 2020\end{array}$ & $15-2-2020$ & The Lancet & Case series & 99 & China & (28) & Fair \\
\hline 9 & $\mathrm{Li}$ and Li, 2020 & $\begin{array}{l}\text { Pre-print: } 12- \\
2-2020\end{array}$ & MDrxiv & Case series & 17 & China & (29) & Fair \\
\hline 10 & Qian, 2020 & $17-3-2020$ & QJM & Case series & 91 & China & (30) & Fair \\
\hline 11 & $\begin{array}{l}\mathrm{Xu} \text { and } \mathrm{Wu} \text {, } \\
2020\end{array}$ & $10-2-2020$ & BMJ & Case series & 62 & China & $(31)$ & Fair \\
\hline 12 & $\begin{array}{l}\text { Huang and } \\
\text { Wang, } 2020\end{array}$ & $24-1-2020$ & Lancet & Case series & 41 & China & (32) & Fair \\
\hline 13 & Wan, 2020 & $21-3-2020$ & Journal of Medical Virology & Case Series & 135 & China & (33) & Fair \\
\hline 14 & $\begin{array}{l}\text { Yang and Yu, } \\
2020\end{array}$ & $24-2-2020$ & The Lancet Respiratory Medicine & $\begin{array}{c}\text { Cohort - } \\
\text { Retrospective }\end{array}$ & 52 & China & (34) & Fair \\
\hline 15 & $\begin{array}{l}\text { Liu and Fang, } \\
2020\end{array}$ & $7-2-2020$ & Chinese Medical Journal & Case series & 137 & China & (35) & Fair \\
\hline 16 & Guan, 2020 & $28-2-2020$ & The new england journal of medicine & Case series & 1099 & China & (2) & Fair \\
\hline 17 & $\begin{array}{l}\text { Wang and } \mathrm{Hu} \text {, } \\
2020\end{array}$ & $7-2-2020$ & JAMA & Case series & 138 & China & (36) & Fair \\
\hline 18 & $\begin{array}{l}\text { Qin and Qiu, } \\
2020\end{array}$ & $\begin{array}{l}\text { Pre-print: } 20- \\
\text { 2-2020 }\end{array}$ & TheLancet & Case series & 89 & China & (37) & Good \\
\hline 19 & $\begin{array}{l}\text { Yang and Cao, } \\
2020\end{array}$ & $26-2-2020$ & The Journal of Infection & Case series & 149 & China & (38) & Fair \\
\hline 20 & $\begin{array}{l}\text { Qin and Zhou, } \\
2020\end{array}$ & $12-3-2020$ & Clinical Infectious Diseases & Case series & 452 & China & (39) & Fair \\
\hline 21 & $\begin{array}{l}\text { Liu and Liu, } \\
2020\end{array}$ & $12-2-2020$ & Preprint: medRxiv & Case series & 61 & China & $(40)$ & Fair \\
\hline 22 & Easom, 2020 & $29-3-2020$ & Influenza Other Respir Viruses & Case series & 68 & UK & $(41)$ & Fair \\
\hline 23 & Deng, 2020 & $20-3-2020$ & Chinese Medical Journal & Case series & 225 & China & $(42)$ & Good \\
\hline 24 & $\begin{array}{c}\text { Huang and Tu, } \\
2020\end{array}$ & $27-2-2020$ & Travel Medicine and Infectious Disease & Case series & 34 & China & $(43)$ & Fair \\
\hline 25 & Mo, 2020 & $16-3-2020$ & Clinical Infectious Diseases & Case series & 155 & China & $(44)$ & Fair \\
\hline 26 & $\begin{array}{l}\text { Li and Wang, } \\
2020\end{array}$ & $\begin{array}{l}\text { Pre-print:17- } \\
\text { 3-2020 }\end{array}$ & The Lancet & Case series & 221 & China & $(10)$ & Good \\
\hline
\end{tabular}




\begin{tabular}{|c|c|c|c|c|c|c|c|c|}
\hline 27 & $\begin{array}{l}\text { Zheng and } \\
\text { Tang, } 2020\end{array}$ & $24-3-2020$ & $\begin{array}{l}\text { European Review for Medical and } \\
\text { Pharmacological Sciences }\end{array}$ & Case series & 161 & China & $(45)$ & Fair \\
\hline 28 & Guo, 2020 & $\begin{array}{c}\text { Pre-print: } 14- \\
4-2020\end{array}$ & The Lancet & Case series & 118 & China & $(46)$ & Good \\
\hline 29 & Yan, 2020 & \begin{tabular}{|l|} 
Pre-print: 6-4- \\
2020
\end{tabular} & The Lancet & Case series & 218 & China & $(47)$ & Good \\
\hline 30 & Chang, 2020 & $17-3-2020$ & JAMA & Case series & 13 & China & $(48)$ & Fair \\
\hline 31 & $\begin{array}{l}\text { Wang and Pan, } \\
2020\end{array}$ & $\begin{array}{c}\text { Pre-proof: } 11- \\
4-2020\end{array}$ & $\begin{array}{c}\text { International Journal of Infectious } \\
\text { Diseases }\end{array}$ & Case series & 125 & China & $(49)$ & Fair \\
\hline 32 & $\begin{array}{c}\text { Zhou and Sun, } \\
2020\end{array}$ & \begin{tabular}{|l|} 
Pre-print: 16- \\
3-2020
\end{tabular} & BMC Infectious Diseases & Case series & 201 & China & $(50)$ & Fair \\
\hline 33 & $\begin{array}{c}\text { Zheng and Xu, } \\
2020\end{array}$ & $10-4-2020$ & Journal of Clinical Virology & Case series & 99 & China & $(51)$ & Fair \\
\hline 34 & Helms, 2020 & $15-4-2020$ & NEJM & Case series & 58 & France & $(52)$ & Fair \\
\hline 35 & Lechien, 2020 & $6-4-2020$ & $\begin{array}{c}\text { European Archives of Oto-Rhino- } \\
\text { Laryngology }\end{array}$ & $\begin{array}{c}\text { Cross-Sectional } \\
\text { Study }\end{array}$ & 417 & $\begin{array}{l}\text { Belgium, France, } \\
\text { Spain, Italy }\end{array}$ & (53) & Fair \\
\hline 36 & $\begin{array}{l}\text { Chen and } \\
\text { Chen, } 2020\end{array}$ & \begin{tabular}{|c|} 
Pre-print: $1-4-$ \\
2020
\end{tabular} & The Lancet & Case series & 85 & China & $(54)$ & Fair \\
\hline 37 & Jiang, 2020 & $\begin{array}{l}\text { Pre-print: } 14- \\
\text { 4-2020 }\end{array}$ & medRxiv & Case series & 55 & China & (55) & Good \\
\hline 38 & Zhang, 2020 & $\begin{array}{c}\text { Pre-proof: 9- } \\
4-2020\end{array}$ & Journal of Clinical Virology & Case series & 221 & China & $(56)$ & Fair \\
\hline 39 & Tabata, 2020 & \begin{tabular}{|l|} 
Pre-print: 18- \\
3-2020
\end{tabular} & The Lancet & Case series & 104 & Japan & $(57)$ & Fair \\
\hline 40 & Lei, 2020 & $\begin{array}{c}\text { Pre-proof: 9- } \\
4-2020\end{array}$ & Travel Medicine and Infectious Disease & Case series & 20 & Guangzhou, China & $(58)$ & Fair \\
\hline 41 & $\begin{array}{l}\text { Zhou and Yu, } \\
2020\end{array}$ & $28-3-2020$ & The Lancet & $\begin{array}{l}\text { Cohort - } \\
\text { Retrospective }\end{array}$ & 191 & China & (59) & Fair \\
\hline 42 & Spinato, 2020 & $22-4-2020$ & JAMA & $\begin{array}{l}\text { Cross-sectional } \\
\text { Study }\end{array}$ & 202 & Italy & $(60)$ & Fair \\
\hline 43 & Klok, 2020 & $10-4-2020$ & Thrombosis Research & Case series & 184 & Netherlands & $(61)$ & Fair \\
\hline 44 & CNIRST, 2020 & $19-4-2020$ & NA & Case series & 6,606 & Australia & $(62)$ & Fair \\
\hline
\end{tabular}

DD/MM/Y, Day, Month, Year. NA, not applicable

Table 2: Characteristics of Included Case Reports 


\begin{tabular}{|c|c|c|c|c|c|c|c|}
\hline \# & Author & $\begin{array}{c}\text { Date } \\
(\mathrm{DD} / \mathrm{MM} / \mathrm{Y})\end{array}$ & Journal & $\begin{array}{l}\text { Study } \\
\text { type }\end{array}$ & $\mathbf{N}$ & Country & Reference \\
\hline 1 & Moriguchi, 2020 & $\begin{array}{l}\text { Pre-Print: } 25-3- \\
2020\end{array}$ & International Journal of Infectious Diseases & $\begin{array}{c}\text { Case } \\
\text { Report }\end{array}$ & 1 & Japan & (11) \\
\hline 2 & Zhao and huang, 2020 & $\begin{array}{l}\text { Pre-Print: 9-4- } \\
2020\end{array}$ & medRxiv preprint & $\begin{array}{c}\text { Case } \\
\text { Report }\end{array}$ & 1 & China & (63) \\
\hline 3 & Lorenzo Villalba, 2020 & $3-4-2020$ & $\begin{array}{c}\text { European Journal of Case Reports in Internal } \\
\text { Medicine }\end{array}$ & $\begin{array}{c}\text { Case } \\
\text { Report }\end{array}$ & 2 & $\begin{array}{l}\text { France and } \\
\text { Spain }\end{array}$ & (64) \\
\hline 4 & Ollarves-Carrero, 2020 & $13-4-2020$ & Travel Medicine and Infectious Disease & $\begin{array}{l}\text { Case } \\
\text { Report }\end{array}$ & 1 & Spain & (65) \\
\hline 5 & Sharifi-Razavi, 2020 & $27-3-2020$ & New Microbes and New Infections & $\begin{array}{c}\text { Case } \\
\text { Report }\end{array}$ & 1 & Iran & (66) \\
\hline 6 & $\begin{array}{l}\text { Marchese-Ragona, } \\
2020\end{array}$ & $\begin{array}{l}\text { Pre-print: 7-4- } \\
2020\end{array}$ & MedRxiv preprint & $\begin{array}{c}\text { Case } \\
\text { Report }\end{array}$ & 6 & Italy & (9) \\
\hline 7 & Novi, 2020 & $9-4-2020$ & Multiple sclerosis and related disorders & $\begin{array}{c}\text { Case } \\
\text { Report }\end{array}$ & 1 & Italy & (67) \\
\hline 8 & Poyiadji, 2020 & $31-3-2020$ & Radiology & $\begin{array}{c}\text { Case } \\
\text { Report }\end{array}$ & 1 & USA & $(12)$ \\
\hline 9 & Karimi, 2020 & $24-3-2020$ & Iran Red Crescent Med J & $\begin{array}{c}\text { Case } \\
\text { Report }\end{array}$ & 1 & Iran & (68) \\
\hline 10 & Zhao and shen, 2020 & $1-4-2020$ & Lancet Neurology & $\begin{array}{c}\text { Case } \\
\text { Report }\end{array}$ & 1 & China & (69) \\
\hline 11 & Gane, 2020 & $29-3-2020$ & Rhinology & $\begin{array}{c}\text { Case } \\
\text { Report }\end{array}$ & 1 & United Kingdom & $(70)$ \\
\hline 12 & Hjelmesæth, 2020 & $5-4-2020$ & Tidsskr Nor Legeforen & $\begin{array}{c}\text { Case } \\
\text { Report }\end{array}$ & 3 & Norway & (71) \\
\hline 13 & Toscano, 2020 & $17-4-2020$ & NEJM & $\begin{array}{c}\text { Case } \\
\text { Report }\end{array}$ & 5 & Italy & $(72)$ \\
\hline 14 & Filatov, 2020 & $21-3-2020$ & Cureus & $\begin{array}{c}\text { Case } \\
\text { Report }\end{array}$ & 1 & USA & (8) \\
\hline 15 & Suwanwongse, 2020 & $6-4-2020$ & Cureus & $\begin{array}{c}\text { Case } \\
\text { Report }\end{array}$ & 1 & USA & (73) \\
\hline 16 & $\begin{array}{l}\text { Wang and Hajizadeh, } \\
2020\end{array}$ & 08-04-2020 & Journal of Thrombosis and Haemostasis & $\begin{array}{c}\text { Case } \\
\text { Report }\end{array}$ & 3 & USA & (74) \\
\hline 17 & Wang and Chen, 2020 & 09-02-2020 & Bioscience Trends & $\begin{array}{c}\text { Case } \\
\text { Report }\end{array}$ & 4 & China & (75) \\
\hline 18 & Ren, 2020 & 05-05-2020 & Chinese Medical Journal & $\begin{array}{c}\text { Case } \\
\text { Report }\end{array}$ & 5 & China & (76) \\
\hline 19 & Rothe, 2020 & 05-03-2020 & NEJM & $\begin{array}{c}\text { Case } \\
\text { Report }\end{array}$ & 1 & Germany & (77) \\
\hline 20 & Wang and Tang, 2020 & $27-01-2020$ & Journal of Medical Virology & $\begin{array}{c}\text { Case } \\
\text { Report }\end{array}$ & 17 & China & (78) \\
\hline
\end{tabular}

DD/MM/Y, Day, Month, Year.

Table 3: Meta-analysis of the clinical characteristics of the study subjects 


\begin{tabular}{|c|c|c|c|c|c|c|}
\hline & Pooled effect size & \multicolumn{3}{|c|}{ Heterogeneity } & \multirow[t]{2}{*}{ Tau squared } & \multirow[t]{2}{*}{ \# of studies } \\
\hline & & $Q$ value & $P$ value & I Squared & & \\
\hline Mean age (Years) & $50.3(47.7-52.9)$ & 2872.2 & $<.001$ & 98.50 & 72.58 & 44 \\
\hline Male & $53.0(50.2-55.7) \%$ & 180.71 & $<.001$ & 77.31 & 8.97 & 42 \\
\hline \multicolumn{7}{|l|}{ Clinical features } \\
\hline Headache & $12.1(9.1-15.8) \%$ & 989.99 & $<.001$ & 96.26 & 0.824 & 38 \\
\hline Myalgia & $22.2(17.2-28.1) \%$ & 621.55 & $<.001$ & 94.85 & 0.740 & 33 \\
\hline Taste impairment & 19.6 (3.8-60.1) \% & 431.04 & $<.001$ & 99.30 & 3.405 & 4 \\
\hline Smell impairment & $18.3(1.54-76.2) \%$ & 853.88 & $<.001$ & 99.64 & 7.254 & 4 \\
\hline Dizziness & 11.3 (8.5-15.0) \% & 27.85 & .001 & 67.68 & 0.156 & 10 \\
\hline Features of encephalopathy or cognitive dysfunction & $9.4(2.8-26.6) \%$ & 133.92 & $<.001$ & 95.51 & 2.70 & 7 \\
\hline Ataxia or abnormal gait & $2.1(0.2-23.7) \%$ & 6.59 & .010 & 84.83 & 3.18 & 2 \\
\hline Fever & $80.6(74.9-85.3) \%$ & 1604.55 & $<.001$ & 97.44 & 1.05 & 42 \\
\hline Cough & $64.1(59.9-68.0) \%$ & 575.30 & $<.001$ & 93.04 & 0.26 & 41 \\
\hline Neurological complications * & $3.0(0.9-9.6) \%$ & 50.01 & $<.001$ & 92.00 & 1.66 & 5 \\
\hline Acute CVD & $2.5(1.0-6.1) \%$ & 15.3 & 0.004 & 74.41 & 0.72 & 5 \\
\hline \multicolumn{7}{|l|}{ Laboratory findings } \\
\hline Serum CK (U/L) & $85.5(73.8-97.3)$ & 369.93 & $<.001$ & 96.21 & 434.78 & 15 \\
\hline Serum LDH (U/L) & $263.4(234.6-292.3)$ & 648.50 & $<.001$ & 97.84 & 3026.56 & 15 \\
\hline Lymphocyte $\left(* 10^{\wedge} 9 / \mathrm{L}\right)$ & $1.08(1.02-1.14)$ & 549.37 & $<.001$ & 95.08 & 0.024 & 28 \\
\hline Neutrophils $\left(* 10^{\wedge} 9 / \mathrm{L}\right)$ & $3.44(3.21-3.68)$ & 214.45 & $<.001$ & 90.67 & 0.244 & 21 \\
\hline Monocytes $\left(* 10^{\wedge} 9 / \mathrm{L}\right)$ & $0.39(0.37-0.42)$ & 42.66 & $<.001$ & 78.90 & 0.001 & 10 \\
\hline Severe COVID-19 & $31.1(21.9-42.2) \%$ & 739.23 & $<.001$ & 97.02 & 1.16 & 23 \\
\hline ICU admission & $20.6(14.1-29.0) \%$ & 231.12 & $<.001$ & 91.34 & 0.81 & 21 \\
\hline \multicolumn{7}{|l|}{ Comorbidities } \\
\hline Any previous comorbidity & $37.4(33.1-41.9) \%$ & 274.90 & $<.001$ & 89.08 & 0.231 & 31 \\
\hline Diabetes Mellitus & $10.3(8.3-12.8) \%$ & 265.15 & $<.001$ & 88.68 & 0.360 & 31 \\
\hline Hypertension & $20.4(17.0-24.2) \%$ & 196.73 & $<.001$ & 87.292 & 0.253 & 26 \\
\hline Heart diseases & 9.7 (7.2-12.9) \% & 426.59 & $<.001$ & 93.201 & 0.706 & 30 \\
\hline Neurological diseases & $5.7(3.3-9.7) \%$ & 175.60 & $<.001$ & 90.319 & 1.213 & 18 \\
\hline
\end{tabular}




\begin{tabular}{|c|c|c|c|c|c|c|}
\hline Malignancy & $2.7(2.0-3.6) \%$ & 61.429 & $<.001$ & 59.303 & 0.319 & 26 \\
\hline Pulmonary diseases & $3.4(2.2-5.0) \%$ & 260.24 & $<.001$ & 89.240 & 0.973 & 29 \\
\hline Chronic kidney disease & $2.3(1.3-3.9) \%$ & 75.189 & $<.001$ & 81.380 & 0.858 & 15 \\
\hline Chronic liver disease & $3.5(2.6-4.7) \%$ & 32.726 & .005 & 54.165 & 0.187 & 16 \\
\hline Smoking & $9.2(6.4-13.0) \%$ & 146.643 & $<.001$ & 89.771 & 0.501 & 16 \\
\hline
\end{tabular}

*Neurological complications include: Cerebrovascular diseases (ischemic stroke, cerebral hemorrhage, and venous sinus thrombosis), rhabdomyolysis, and seizures.

$\mathrm{P}<.05$ indicates the presence of heterogeneity.

Table 4: Subgroup analysis between severe and non-severe groups 


\begin{tabular}{|c|c|c|c|c|c|c|c|c|}
\hline \multirow[t]{2}{*}{ Study } & \multirow[t]{2}{*}{ Subgroup } & \multirow{2}{*}{$\begin{array}{c}\text { Pooled effect } \\
\text { size } \\
(95 \% \mathrm{CI})\end{array}$} & \multicolumn{4}{|c|}{ Heterogeneity } & \multirow{2}{*}{$\begin{array}{c}\text { Tau } \\
\text { squared }\end{array}$} & \multirow{2}{*}{$\begin{array}{c}\text { Mixed effects } \\
\text { analysis } \\
P \text { value }\end{array}$} \\
\hline & & & $\mathrm{Q}$ value & $\begin{array}{l}\text { Df } \\
(Q)\end{array}$ & $\begin{array}{c}P \text { value } \\
\dagger\end{array}$ & $\begin{array}{c}\text { I } \\
\text { Squared }\end{array}$ & & \\
\hline \multirow[t]{3}{*}{ Age (Years) } & Total & $\begin{array}{c}56.9(55.1- \\
58.8)\end{array}$ & 1443.18 & 34 & $<.001$ & 97.64 & 107.603 & $<.001$ \\
\hline & $\begin{array}{c}\text { Non } \\
\text { severe }\end{array}$ & $\begin{array}{c}44.4(40.1- \\
48.7)\end{array}$ & 585.98 & 16 & $<.001$ & 97.26 & 77.40 & \\
\hline & Severe & $\begin{array}{c}60.0(57.9- \\
62.1)\end{array}$ & 78.77 & 17 & $<.001$ & 78.418 & 13.35 & \\
\hline \multirow[t]{3}{*}{ Male } & Total & $\begin{array}{c}53.1(49.5- \\
56.6) \%\end{array}$ & 108.58 & 31 & $<.001$ & 71.45 & 0.104 & .001 \\
\hline & $\begin{array}{c}\text { Non } \\
\text { severe }\end{array}$ & $\begin{array}{c}48.6(44.2- \\
53.1) \%\end{array}$ & 54.23 & 15 & $<.001$ & 72.34 & 0.082 & \\
\hline & Severe & $\begin{array}{c}60.3(54.7- \\
65.7) \%\end{array}$ & 36.90 & 15 & .001 & 59.36 & 0.104 & \\
\hline \multicolumn{9}{|l|}{ Clinical features } \\
\hline \multirow[t]{3}{*}{ Headache } & Total & $\begin{array}{c}14.8(12.4- \\
17.5) \%\end{array}$ & 187.25 & 30 & $<.001$ & 83.97 & 0.474 & .308 \\
\hline & $\begin{array}{c}\text { Non } \\
\text { severe }\end{array}$ & $\begin{array}{c}12.2(7.9-18.2) \\
\%\end{array}$ & 170.26 & 15 & $<.001$ & 91.19 & 0.730 & \\
\hline & Severe & $\begin{array}{c}15.4(12.7- \\
18.5) \%\end{array}$ & 16.27 & 14 & .296 & 14.003 & 0.025 & \\
\hline \multirow[t]{3}{*}{ Myalgia } & Total & $\begin{array}{c}24.4(18.2- \\
32.0) \%\end{array}$ & 167.89 & 18 & $<.001$ & 89.279 & 0.468 & .045 \\
\hline & $\begin{array}{c}\text { Non } \\
\text { severe }\end{array}$ & $\begin{array}{c}19.4(13.1- \\
27.9) \%\end{array}$ & 102.34 & 9 & $<.001$ & 91.206 & 0.463 & \\
\hline & Severe & $\begin{array}{c}34.9(22.3- \\
49.9) \%\end{array}$ & 58.061 & 8 & $<.001$ & 86.221 & 0.651 & \\
\hline \multirow[t]{3}{*}{ Dizziness } & Total & $\begin{array}{c}11.9(8.7-16.0) \\
\%\end{array}$ & 16.073 & 7 & 0.024 & 56.449 & 0.106 & .506 \\
\hline & $\begin{array}{c}\text { Non } \\
\text { severe }\end{array}$ & $\begin{array}{c}10.9(7.4-16.1) \\
\%\end{array}$ & 10.27 & 4 & 0.036 & 61.076 & 0.145 & \\
\hline & Severe & $\begin{array}{c}13.5(8.2-21.5) \\
\%\end{array}$ & 5.619 & 2 & 0.06 & 64.409 & 0.152 & \\
\hline \multirow{3}{*}{$\begin{array}{l}\text { Features of Encephalopathy / cognitive } \\
\text { dysfunction }\end{array}$} & Total & $3.2(1.2-8.4) \%$ & 116.97 & 6 & $<.001$ & 94.87 & 4.753 & .054 \\
\hline & $\begin{array}{c}\text { Non } \\
\text { severe }\end{array}$ & $1.9(0.6-5.8) \%$ & 2.266 & 2 & .322 & 11.743 & 0.167 & \\
\hline & Severe & & & & & & & \\
\hline
\end{tabular}




\begin{tabular}{|c|c|c|c|c|c|c|c|c|}
\hline & & $\begin{array}{c}16.9(2.4-62.3) \\
\%\end{array}$ & 83.34 & 3 & $<.001$ & 96.4 & 4.342 & \\
\hline \multirow[t]{3}{*}{ Fever } & Total & $\begin{array}{c}79.8 \text { (71.6- } \\
86.2) \%\end{array}$ & 560.33 & 31 & $<.001$ & 94.46 & 1.159 & .213 \\
\hline & $\begin{array}{c}\text { Non } \\
\text { severe }\end{array}$ & $\begin{array}{c}76.9(66.3- \\
85.0) \%\end{array}$ & 313.83 & 15 & $<.001$ & 95.22 & 0.912 & \\
\hline & Severe & $\begin{array}{c}86.5 \text { (72.6- } \\
93.9) \%\end{array}$ & 238.40 & 15 & $<.001$ & 93.708 & 2.63 & \\
\hline \multirow[t]{3}{*}{ Cough } & Total & $\begin{array}{c}59.2(52.8- \\
65.3) \%\end{array}$ & 285.48 & 30 & $<.001$ & 89.49 & 0.402 & .094 \\
\hline & $\begin{array}{c}\text { Non } \\
\text { severe }\end{array}$ & $\begin{array}{c}55.8(48.2- \\
63.2) \%\end{array}$ & 141.37 & 15 & $<.001$ & 89.39 & 0.302 & \\
\hline & Severe & $\begin{array}{c}67.4(55.9- \\
77.2) \%\end{array}$ & 135.46 & 14 & $<.001$ & 89.66 & 0.734 & \\
\hline \multirow[t]{3}{*}{ Neurological Complications } & Total & $\begin{array}{c}3.8(1.3-10.0) \\
\%\end{array}$ & 82.532 & 7 & $<.001$ & 91.518 & 2.274 & .212 \\
\hline & $\begin{array}{c}\text { Non } \\
\text { severe }\end{array}$ & $1.3(0.2-8.8) \%$ & 17.178 & 2 & $<.001$ & 88.35 & 2.663 & \\
\hline & Severe & $\begin{array}{c}5.6(1.7-17.1) \\
\%\end{array}$ & 37.55 & 4 & $<.001$ & 89.34 & 1.607 & \\
\hline \multirow[t]{3}{*}{ Acute CVD* } & Total & $2.6(1.1-5.8) \%$ & 33.02 & 7 & $<.001$ & 78.91 & 1.42 & .045 \\
\hline & $\begin{array}{c}\text { Non } \\
\text { severe }\end{array}$ & $0.6(0.1-3.1) \%$ & 4.578 & 2 & 0.101 & 56.319 & 1.299 & \\
\hline & Severe & $\begin{array}{c}4.1(1.6-10.0) \\
\%\end{array}$ & 15.38 & 4 & 0.004 & 74.00 & 0.797 & \\
\hline \multicolumn{9}{|l|}{ Laboratory findings } \\
\hline \multirow[t]{3}{*}{ Serum CK } & Total & $\begin{array}{c}91.5(79.3- \\
103.7)\end{array}$ & 90.95 & 15 & $<.001$ & 83.505 & 377.38 & .01 \\
\hline & $\begin{array}{c}\text { Non } \\
\text { severe }\end{array}$ & $\begin{array}{c}83.0(69.1- \\
96.8)\end{array}$ & 53.346 & 7 & $<.001$ & 86.87 & 276.03 & \\
\hline & Severe & $\begin{array}{c}121.2(95.4- \\
147.1)\end{array}$ & 18.80 & 7 & $<.001$ & 62.76 & 633.03 & \\
\hline \multirow[t]{3}{*}{ Serum LDH } & Total & $\begin{array}{c}270.6(243.1- \\
298.1)\end{array}$ & 494.931 & 15 & $<.001$ & 96.969 & 3099.14 & .012 \\
\hline & $\begin{array}{c}\text { Non } \\
\text { severe }\end{array}$ & $\begin{array}{c}247.6(214.8- \\
280.4)\end{array}$ & 272.42 & 7 & $<.001$ & 97.43 & 1997.9 & \\
\hline & Severe & $\begin{array}{c}324.9(274.4- \\
375.4)\end{array}$ & 66.42 & 7 & $<.001$ & 89.462 & 4195.36 & \\
\hline \multirow[t]{2}{*}{ Preexisting neurological diseases } & Total & $4.5(2.8-7.0) \%$ & 101.58 & 20 & $<.001$ & 80.31 & 1.055 & .072 \\
\hline & Non & $2.6(1.2-5.5) \%$ & 36.692 & 9 & $<.001$ & 78.19 & 0.970 & \\
\hline
\end{tabular}




\begin{tabular}{|c|c|c|c|c|c|c|l|} 
severe & & & & & & & \\
\hline Severe & $\begin{array}{c}6.2(3.5-10.9) \\
\%\end{array}$ & 42.959 & 11 & $<.001$ & 74.39 & 0.772 & \\
\hline
\end{tabular}

*CVD (Cerebrovascular diseases): Ischemic stroke, cerebral hemorrhage, and venous sinus thrombosis. $\dagger \mathrm{P}<.05$ indicates the presence of heterogeneity.

Table 5: Patients characteristics and findings of the included case reports 


\begin{tabular}{|c|c|c|c|c|c|}
\hline Variable & & $\begin{array}{c}\mathrm{N}(\%) \text { or } \\
\text { Mean } \pm \mathrm{SD}\end{array}$ & Variable & & $\begin{array}{c}\mathrm{N}(\%) \text { or } \\
\text { Mean } \pm \text { SD }\end{array}$ \\
\hline \multirow[t]{2}{*}{ Number } & Cases & 57 & \multirow[t]{15}{*}{ Clinical features } & Fever & $41(71.9 \%)$ \\
\hline & Articles & 20 & & Cough & $34(59.6 \%)$ \\
\hline \multirow{10}{*}{$\begin{array}{l}\text { Countries of the cases } \\
\text { reported }\end{array}$} & China & $28(49.1 \%)$ & & Fatigue & $14(25.6 \%)$ \\
\hline & Italy & $12(21.0 \%)$ & & Myalgia & $12(21.0 \%)$ \\
\hline & USA & $6(10.5 \%)$ & & Headache & $5(8.8 \%)$ \\
\hline & Norway & $3(5.3 \%)$ & & Dizziness & $2(3.5 \%)$ \\
\hline & Iran & $2(3.5 \%)$ & & Taste impairment & $11(19.3 \%)$ \\
\hline & Spain & $2(3.5 \%)$ & & Smell impairment & $13(22.8 \%)$ \\
\hline & France & $1(1.8 \%)$ & & Encephalopathy features & $5(8.8 \%)$ \\
\hline & Germany & $1(1.8 \%)$ & & Weakness/ paralysis & $7(12.3 \%)$ \\
\hline & Japan & $1(1.8 \%)$ & & Altered reflexes & $3(5.3 \%)$ \\
\hline & UK & $1(1.8 \%)$ & & Altered sensation** & $5(8.8 \%)$ \\
\hline Age (Years) & & $59.5 \pm 20.2$ & & Ataxia or abnormal gait & $1(1.8 \%)$ \\
\hline \multirow[t]{2}{*}{ Gender } & Male & $38(66.6 \%)$ & & Facial weakness & $4(7 \%)$ \\
\hline & Female & $19(33.3 \%)$ & & Neck pain/ rigidity & $2(3.5 \%)$ \\
\hline \multirow[t]{9}{*}{ Comorbidities } & Any & $24(42.1 \%)$ & \multirow{3}{*}{$\begin{array}{l}\text { Number of neurological } \\
\text { manifestations }\end{array}$} & None & $20(35.0 \%)$ \\
\hline & $\mathrm{DM}$ & $7(12.3 \%)$ & & $1-2$ & $27(47.3 \%)$ \\
\hline & Hypertension & $13(22.8 \%)$ & & $>3$ & $10(17.5 \%)$ \\
\hline & $\begin{array}{c}\text { Cardiovascular } \\
\text { diseases }\end{array}$ & $9(15.7 \%)$ & \multirow[t]{8}{*}{ Neurological complications } & Any & $12(21.0 \%)$ \\
\hline & $\begin{array}{l}\text { Neurological } \\
\text { diseases }\end{array}$ & $8(14.0 \%)$ & & GBS & $6(10.5 \%)$ \\
\hline & $\begin{array}{l}\text { Chronic liver } \\
\text { diseases }\end{array}$ & $3(5.2 \%)$ & & Encephalitis & $2(3.5 \%)$ \\
\hline & $\begin{array}{l}\text { Pulmonary } \\
\text { diseases }\end{array}$ & $5(8.8 \%)$ & & Seizure & $2(3.5 \%)$ \\
\hline & $\begin{array}{l}\text { Malignancy or } \\
\text { cancer }\end{array}$ & $1(1.8 \%)$ & & Cerebral Hemorrhage & $1(1.8 \%)$ \\
\hline & $\begin{array}{c}\text { Chronic kidney } \\
\text { disease }\end{array}$ & $4(7 \%)$ & & Myelitis & $1(1.8 \%)$ \\
\hline \multirow[t]{3}{*}{ ICU } & Yes & $\begin{array}{c}16 \text { out of } 28 \\
(57.1 \%)\end{array}$ & & Rhabdomyolysis & $1(1.8 \%)$ \\
\hline & No & $\begin{array}{c}12 \text { out of } 28 \\
(42.8 \%)\end{array}$ & & Onset (Days)* & $7.25 \pm 2.43$ \\
\hline & Onset (Days) * & $7.7 \pm 2.9$ & Imaging & CT/MRI changes & $6(10.5 \%)$ \\
\hline \multirow[t]{2}{*}{ Ventilator } & Yes & $\begin{array}{c}11 \text { out of } 31 \\
(35.4 \%)\end{array}$ & \multirow[t]{2}{*}{ CSF } & Increased protein & $5(8.8 \%)$ \\
\hline & No & $\begin{array}{c}20 \text { out of } 31 \\
(64.5 \%)\end{array}$ & & SARS-CoV-2 RNA in CSF & $1(1.8 \%)$ \\
\hline
\end{tabular}




\begin{tabular}{|c|c|c|c|c|c|}
\hline & Onset (Days) * & $7 \pm 2.49$ & EEG & $\begin{array}{c}\text { Temporal slowing and } \\
\text { sharp waves }\end{array}$ & $1(1.8 \%)$ \\
\hline \multirow[t]{3}{*}{ Severity of COVID-19 } & Asymptomatic & $3(5.3 \%)$ & $\begin{array}{l}\text { Nerve conduction } \\
\text { study/EMG }\end{array}$ & $\begin{array}{l}\text { Demyelinating or Axonal } \\
\text { patterns }\end{array}$ & $6(10.5 \%)$ \\
\hline & Non-severe & $19(33.3 \%)$ & $\begin{array}{l}\text { Neurology-related } \\
\text { management }\end{array}$ & & $12(21 \%)$ \\
\hline & Severe & $30(52.6 \%)$ & Neurological outcome & Morbidity/ disability & $\begin{array}{c}4 \text { out of } 16 \\
(25 \%)\end{array}$ \\
\hline \multirow[t]{3}{*}{$\begin{array}{l}\text { COVID-19 disease } \\
\text { outcome }\end{array}$} & Death & $\begin{array}{c}20 \text { out of } 45 \\
(44.4 \%)\end{array}$ & & Recovery/ Improvement & $\begin{array}{c}10 \text { out of } 16 \\
(62.5 \%)\end{array}$ \\
\hline & $\begin{array}{c}\text { Discharged/ } \\
\text { Recovery }\end{array}$ & $\begin{array}{c}18 \text { out of } 45 \\
(40 \%)\end{array}$ & & Still hospitalized & $\begin{array}{c}2 \text { out of } 16 \\
(12.5 \%)\end{array}$ \\
\hline & Still hospitalized & $\begin{array}{c}7 \text { out of } 45 \\
(15.5 \%)\end{array}$ & & Onset (Days)*ם & $15.5(2.5)$ \\
\hline
\end{tabular}

Some data are missing or not reported. All patients in the aforementioned case reports were confirmed to have COVID-19.

GBS; Guillain-Barré Syndrome

* Onset in relation to the onset of COVID-19 symptoms

口Reported as median and IQR

** Altered sensation included paresthesia, numbness, loss of pain, temperature, or tactile sensations of the lower limbs, upper limbs, or trunk.

\section{Figures}

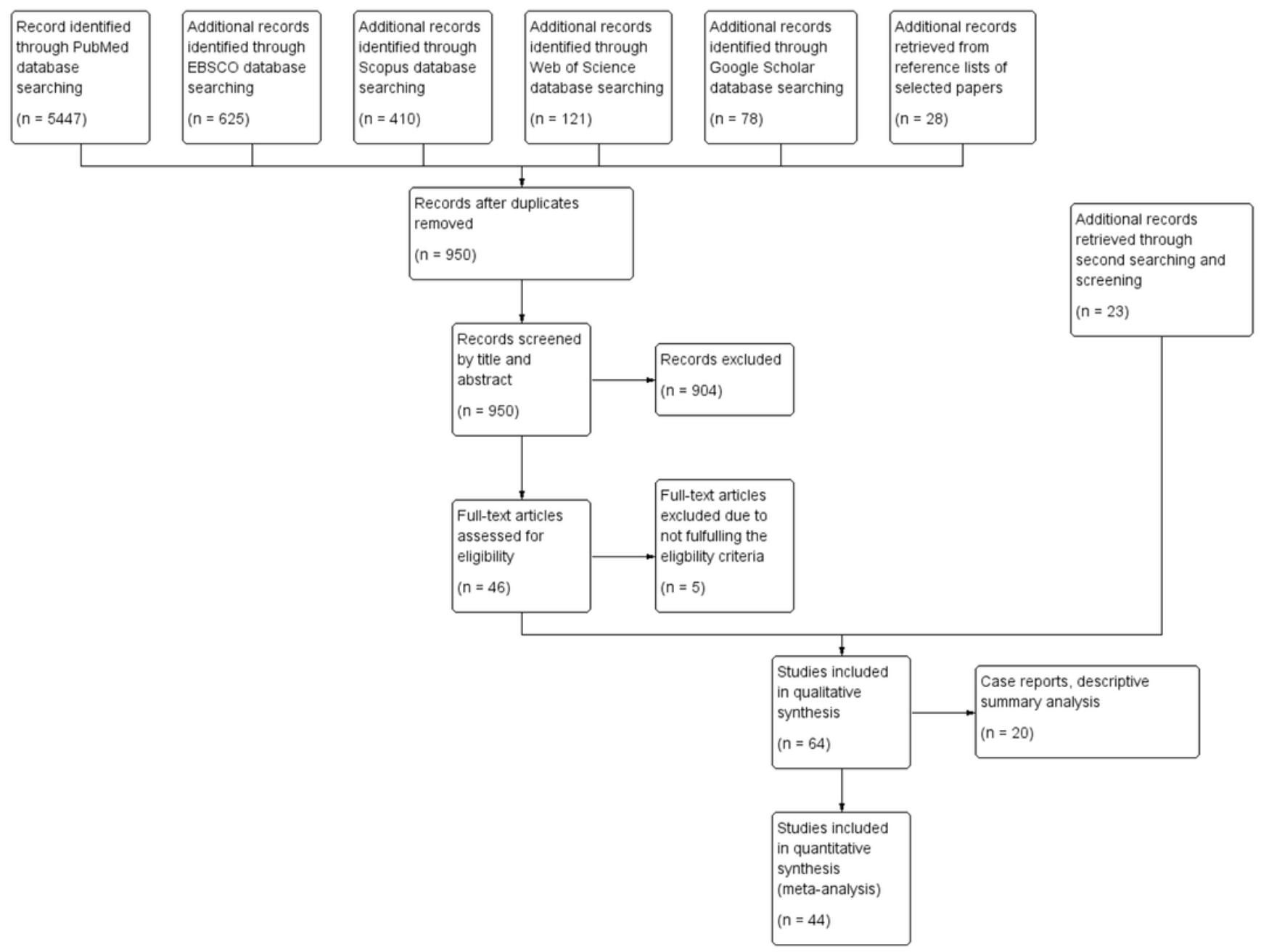




\section{Figure 1}

Flow diagram of study selection

\section{Supplementary Files}

This is a list of supplementary files associated with this preprint. Click to download.

- Additionalfile1.docx

- Additionalfile2.docx

- Additionalfile3.docx

- Additionalfile4.docx

- Additionalfile5.docx

- Additionalfile6.docx

- Additionalfile7.docx

- Additionalfile8.docx

- AdditionalFile9.doc 